\title{
SUSTAINABLE DEVELOPMENT POLICIES AND THE GEOGRAPHICAL LANDSCAPE OF THE GREEN ECONOMY. ACTORS, SCALES AND STRATEGIES
}

ABDELILLAH HAMDOUCH ${ }^{1}$

MARC-HuBERT DEPRET ${ }^{2}$

\begin{abstract}
Following the rise of climate and environmental challenges during the last decade or so, the growing awareness among various actors of sustainability issues at the local and global levels has resulted in a change in public policies as in industrial and financial strategic moves. This change has been rapidly translated into substantial investments both in public and private environmental sectors. Indeed, many "green" technologies and innovations are now reaching the market and more radical ones are being developed through significant Research and Developing (R\&D) investments. However, the development of this emergent "Green Economy" is rather concentrated in certain leading countries or regions. Building on some national examples, the paper explains this phenomenon by the key role played both by the integration and inter-temporal coherence of public policies and by territorial specific settings and permissive conditions.
\end{abstract}

Keywords: Environmental innovations, "Green Economy”, public policies, sustainable development, territorial scales and dynamics.

Resumo - POLÍtICAS DE DESENVOLVIMENTO SUSTENTADO E ECONOMIA VERDE. ACTORES, ESCALAS E ESTRATÉGIAS. Acompanhando os desafios relativos às alterações climáticas e ambientais, a partir pelo menos da última década, a crescente consciência pública da necessidade de encontrar soluções sustentáveis é um desafio para as políticas públicas, à medida que se desenvolvem novas estratégias industriais e financeiras. Estas alterações determinaram investimentos substanciais, tanto públicos como privados, em sectores ambientais. Muitas das tecnologias e inovações "verdes" estão já no mercado e outras, mais radicais, estão a ser estudadas, através de significativos investimentos em pesquisa e desenvolvimento. Apesar de tudo, essa emergente "economia verde" está ainda circunscrita a certos países e regiões. Este texto, baseado em casos de diferentes países, explica este

Recebido: Dezembro 2011. Aceite: Maio 2012.

1 Full Professor of Urban and Regional Planning, Vice-Dean of Planning Department, Polytechnic School, University of Tours. E-mail: abdel-illah.hamdouch@univ-tours.fr

2 Associate-Professor of Economics, University of Poitiers, CRIEF.

E-mail: marc.hubert.depret@univ-poitiers.fr 
fenómeno centrando-se no papel chave desempenhado por políticas públicas e actores regionais.

Palavras-chave: Inovações ambientais, “economia verde”, políticas públicas, desenvolvimento sustentável, escalas territoriais, dinâmicas.

Résumé - Politiques DE DEVELOPPEMENT DURABLE ET DEPLOIEMENT GEOGRAPHIQUE DE L'ECONOMIE VERTE. ACTEURS, ECHELLES ET STRATEGIES. Dans un contexte marqué par le changement climatique et la dégradation de notre écosystème, la prise de conscience croissante, par les différents acteurs du secteur de l'environnement, de la question de la durabilité à l'échelle locale et mondiale a entraîné ces dix dernières années un changement dans les politiques publiques, industrielles et financières. Ce changement s'est rapidement traduit par des investissements importants dans l'environnement, tant dans le secteur public que dans le secteur privé. En effet, de nombreuses technologies et innovations "vertes" sont désormais sur le marché, tandis que bien d'autres, plus radicales, sont en cours de développement. Cependant, le développement de cette "économie verte" en émergence se concentre dans certains grands pays ou régions. En s'appuyant sur quelques exemples nationaux, l'article explique ce phénomène par le rôle clé joué à la fois par la cohérence et l'intégration inter-temporelle des politiques publiques territoriales, et par l'existence préalable de paramètres spécifiques et de conditions permissives.

Mots-clés: Développement durable, "économie verte", innovations environnementales, politiques publiques, échelles territoriales, dynamiques.

\section{INTRODUCTION}

Despite the belated awareness of environmental protection and sustainable development challenges among stakeholders and their limited commitment to these issues, the last few years have seen the emergence and gradual development of a number of innovative environmental products and technologies ${ }^{i}$. Although many consider "technology" to be one of the main causes of climate change and environmental degradation, along with demographic change and economic growth, it also represents a key solution. More "sustainable" technologies, products, services and processes will become available, to a certain extent, over the short to mid-term and can therefore be deployed rapidly if suitable public policies are put in place. The development of more radical environmental technologies (especially in renewable energies) is also already envisaged within the next decade or so with huge potential impact on growth and job creation (at the condition, however, that the considerable financial investments that are required will effectively be engaged). Furthermore, for some authors (Berkhout, 2002; Smith et al., 2005; Nikvist and Whitmarsch, 2008; Suurs and Hekkert, 2009), these technologies may even constitute a "new technoindustrial paradigm" reflecting the engagement of our societies in a "sustainable" (Kemp et al., 1998; Elzen et al., 2004; Kern and Smith, 2008) or "post-carbon era" (Nakicenovic, 1996; Foxon et al., 2008; Grubb et al., 2008; OECD, 2009). This new paradigm is susceptible to impact - and it has more or less already started - in the technological, economic, institutional, organizational and strategic variables of 
many if not most sectors. Moreover, as we aim to show in this article, environmental innovations appear to re-shape the dynamics of many territories (countries, regions, cities) all around the world, through the constitution of "green clusters" around production, research and innovation activities addressing the challenging issues related to sustainable development, to the preservation of the environment and to the attenuation of climate change effects.

This structural momentum towards "green" (or "clean") industries and technologies reflects a change in the way different stakeholders perceive environmental and climate issues in four key areas. Firstly, the environment has become a global and long-term challenge, including changes to the Earth's climate, the depletion of natural resources and multiple impacts on ecosystems, health, crop production, coastal systems, housing, etc., and, as a consequence, on the world economy. It is no longer simply a question of local pollution (atmospheric, groundwater, soil, etc.), which can be reduced relatively quickly. In order to protect the environment and our climate, we need to approach these problems from a global perspective and to take rapid coordinated action, concurrently and across the board (see the recommendations of the Intergovernmental Panel on Climate Change and the "Stern report"). Secondly, the deterioration of the environment can no longer be solely attributed to industrial production processes and consumption patterns now feature prominently in the equation. In this regard, the environment has become a "social issue" and even calls into question aspects of our civilisation. Thirdly, the limited, passive (or corrective) and local management of ecological and climatic degradation is gradually being replaced by the conviction that protecting actively the environment is not necessarily harming growth, job creation and competitiveness - in fact, and in line with "Porter's hypothesis" (Porter, 1991) - it may well produce the (positive) opposing effects. Fourthly and lastly, decision-makers have understood that only a sustainable innovation policy (Foxon and Pearson, 2008; Nill and Kemp, 2009) (i.e. one combining various policies in terms of environment and innovation, but also energy, housing, transport, agriculture, education, regional development, etc. as part of an integrated and co-evolutionary approach) is likely to promote radical environmental innovations with the ability to set in motion the cumulative and long-term development of competitive green sectors at a global and continental level (Kivimaa and Mickwitz, 2006; Jänicke, 2008; Depret and Hamdouch, 2009; Hamdouch and Depret, 2010; Mowery et al., 2010).

This paper aims to further examine the phenomenon of the (industrial, institutional and spatial) emergence and structuring of new (green) growth sectors for products, technologies, processes and services designed to help protect the environment over the long term. We will start by sketching some key features of this "green economy", the main innovations it has produced and the different industries it covers. We will then attempt to identify key public and private initiatives aimed at developing industrial and service activities related to the environment by focusing on those countries most advanced or active in the field. We will go on to show that only a long-term combination of measures pertaining to environment, innovation and other 
policies is likely to promote the emergence, development and dissemination of radical environmental innovations within certain territories. Given the space constraints but also the unavailability of harmonized data from one country to another, it is virtually impossible to provide a detailed account on the development of the green economy and the whole range of related policies that are deployed in many countries around the world. Rather, building on a sample of leading countries whose green business sectors are developing rapidly thanks to very active policies, the aim of the paper is to provide an overview of various national "models". These models reveal that money, despite having an important role to play, is only one of a number of factors and that, as with other issues, there is not "One Best Model" that could be replicated as such in other countries. Finally, the paper concludes by drawing some further research avenues.

\section{THE “GREEN ECONOMY”: OUTLINE AND POTENTIAL}

It is difficult to provide a clear outline of the various "green markets", particularly from a statistical point of view (Depret and Hamdouch, 2009). However, various converging trends provide clear evidence that these markets are now substantial and grow rapidly.

\section{Viable and highly diversified growth markets}

Given this situation, statistical studies provide numerous and sometimes highly varied results depending on the scope of the study (OECD, 2008). However, most studies emphasize the fact that these market niches are now reaching a "critical mass" for the various key stakeholders. These are industrial and service companies (in terms of new markets and funding resources, and of alternative sources of profit); consumers (in terms of the availability of more sustainable goods and services); political decision-makers (in terms of growth and job creation potential, and of territorial development and competitive advantage); and financiers (in terms of investment opportunities).

In 2008, the global turnover generated by environmental technologies was estimated at $\$ 782$ billion (U.S. Department of Commerce, 2010). If we widen the scope and consider the world market of environmental products and services, the current estimates are about $\$ 1,370$ billion; they are expected to double by 2020 (UNEP/ILO, 2008). A study published in 2009 goes even further in estimating that the market of "post-carbon and environmental goods and services" was about $\$ 5,000$ billion ( $£ 3,045$ billion) in 2007-2008 (BERR, 2009). This approach is the largest as it comprises all the activities related to the environment (waste processing, water purification and delivery, de-pollution, etc.), all sectors of renewable energies (wind, photovoltaic, biomass, hydro-electricity, geothermal, etc.), and all the activities designated as being "low-carbon" (nuclear power, alternative fuels, $\mathrm{CO}_{2}$ capture and storage, 
eco-building, "carbon finance", energy management, etc.). However, as evidenced in Table 1, the "geography" of such markets is rather concentrated around only a few key developed and emergent "players" (Depret and Hamdouch, 2012).

The potential of the "green economy" in terms of job creation is equally important. Indeed, various studies (in different countries and for various time-horizons) converge in estimating that the potential of "green jobs" creation (both direct and indirect jobs) is substantial, especially in sectors such as building (eco-building and energy efficiency), energy and personal services (UNEP/ILO, 2008).

Table I - The geographical "landscape" of "Post-Carbon and environmental goods and services" Markets in 2007-2008.

Quadro I-A "paisagem” geográfica de mercados de "bens e serviços pós-carbono”em 2007-2008.

\begin{tabular}{clcc}
\hline Rank & \multicolumn{1}{c}{ Country } & $\begin{array}{c}\text { Value of Market in } \\
2007-2008 \\
(\text { GB£ billions })\end{array}$ & $\begin{array}{c}\text { Share of } \\
\text { World market }(\%)\end{array}$ \\
\hline 1 & United-States & 629.12 & 20.66 \\
2 & China & 411.23 & 13.50 \\
3 & Japan & 191.26 & 6.26 \\
4 & India & 190.81 & 6.28 \\
5 & Germany & 127.58 & 4.19 \\
6 & United-Kingdom & 106.72 & 3.50 \\
7 & France & 92.90 & 3.05 \\
8 & Spain & 83.29 & 2.73 \\
9 & Italy & 81.99 & 2.69 \\
10 & Brazil & 79.54 & 2.61 \\
11 & Russian Federation & 77.23 & 2.53 \\
12 & Mexico & 55.18 & 1,82 \\
13 & Canada & 54.20 & 1,78 \\
14 & South Korea & 49.76 & 1,63 \\
15 & Indonesia & 43.86 & 1,44 \\
16 & Taiwan & 35.05 & 1,15 \\
17 & Australia & 30.85 & 1,01 \\
18 & Argentina & 27.92 & 0,91 \\
19 & Thailand & 27.07 & 0,89 \\
20 & Iran & 27.06 & 0,89 \\
\hline & Rest of the World & 623.21 & 20.48 \\
\hline & Total World Market & 3045.83 & 100.00 \\
\hline
\end{tabular}

Source: Extracted and adapted from BERR (2009).

These expectations or forecasts are recouped by various other indicators or concrete trends observable in several areas. 


\section{Growing interest of major industrial and service groups...}

At the corporate level, a growing number of companies are now adopting a "corporate social responsibility" and sustainable development approach in their organizational and strategic orientations (Ingham et al., 2011), they are also investing and diversifying more and more in "green business" activities. This is particularly noticeable in the cleantech (fuel cells, new materials, energy efficiency, etc.) and renewable energies (agro-fuels, solar and wind energy, biomass, etc.) sectors (IEA, 2008; Pernick et al., 2010; UNEP, 2010) in which the needs are considerable. At the same time, following the Kyoto Protocol ratification, R\&D expenditures, as well as the number of patents and of commercialized innovations in the environmental field have literally boomed (OECD, 2008; Johnstone et al., 2010).

\section{3. ...And from the world of finance}

This fast-growing trend is also observable in the financial sector where both the number and the size of Merger \& Acquisition deals have substantially risen in the recent period (UNEP, 2010). This has been particularly marked in the wind and solar energy sectors (REN21, 2010). Equally, some key actors in the financial sector (venture capital, ethical funds and several pension and investment funds) are becoming more and more attracted to investments in the environmental business. Especially the United-States (NVCA, 2010) and Europe (Payton and Kneller, 2009), but also emerging countries in general, China, India and Brazil in particular (NEF, 2009), are investing progressively more in 'green business'. Developing countries (including emergent countries) are already accounting for more than $28 \%$ market share of total "post-carbon" activities in the world (BERR, 2009; see table I). At the same time they represent $38.8 \%$ of total world investments, in 2009 ( $\$ 46.2$ billion from a total of $\$ 119$ billion) was dedicated to renewable energies and energy efficiency (but excluding R\&D expenses and small-scale investments). Amongst these, China accounts for $\$ 33.7$ billion (i.e. more than the United-States, UK and Germany put together), Brazil accounts for \$7.8 billion, India for \$2.7 billion and Mexico for $\$ 2$ billion (UNEP, 2010). Finally, one should notice that both venture capital companies and private equity funds are extremely involved in the emerging areas (South-America, Asia-Pacific area, the Middle-East and Africa as well) where they invested $\$ 1.3$ billion in 2009 , i.e. $19 \%$ of the World total amount of their investments in environmental sectors (UNEP, 2010). Finally, one should notice the recent fast-development of emission or pollution bonds and carbon funds markets within the key financial places (UNEP, 2010).

\section{The "greening" of public policies}

At the institutional level, the context for the development of the 'green economy' is also becoming increasingly more favourable thanks to various factors. 
Amongst these are: the works of the intergovernmental panel on climate change and the "Stern report"; the increase and volatility of raw materials and energy prices; the installation of the new Administration in the United-States; the financial, economic and social consequences following the subprime crisis; etc. Equally, and in relation with the factor noted above, the "new green economy" is now spurring a growing commitment in many countries and regions of the public authorities, but also of the civil society in those countries and regions. This commitment stems partly from an emergent and consolidating change in mentalities and behaviour of consumers/citizens (Bonini and Oppenheim, 2008), but also from the conviction that recovery from the crisis requires a more sustainable economic growth pattern. As a matter of fact, this new "ecological awareness" translates very concretely in the privileged role given to the "green growth" theme in the "stimuli plans" engaged for amortizing the consequences of the economic crisis started in 2008 (Robins et al., 2009; UNEP, 2010). Within the scope of their respective "stimuli plans", the 15 most developed countries in the World have decided to invest a total of $\$ 187.6$ billion in "green sectors" (UNEP, 2010). Among them, the United-States ( $\$ 66.6$ billion), China ( $\$ 46.9$ billion), South Korea ( $\$ 24.7$ billion) and Germany ( $\$ 15.3$ billion) have been the most active in this area.

\section{The emergence of "green clusters" and environmental innovation networks}

Lastly, and very importantly vis-à-vis the new territorial dynamics underlying the development of the 'green economy', there is currently a move towards the formation of clusters and networks focusing on activities, research and innovation in these environmental fields (Christiansen and Buen, 2002; Brown et al., 2007; Barreto and Kemp, 2008; Foxon and Pearson, 2008; Mans et al., 2008; Lehmann et al., 2009; Cooke, 2010; Madsen and Andersen, 2010). In this article, we consider that a cluster is a spatial mode for the organization of entrepreneurship, innovation and related activities (Depret and Hamdouch, 2011). It "comprises an ensemble of various organizations and institutions that: (a) are defined by respective geographic localizations occurring at varied spatial scales and within specific institutional environments; (b) interact formally and/or informally through inter-organizational and/or interpersonal regular or more occasional relationships and networks, and (c) contribute collectively to the achievement of all kinds of innovations within a given industry or domain of activity, i.e. within a domain defined by specific fields of knowledge, competences and technologies. This definition is rather flexible, as it entails only that the three sets of conditions are verified simultaneously. It could then correspond to a large variety of spatial, institutional and organizational concrete configurations of innovative dynamics. Moreover, it does not prejudge the spatial topography of the interacting actors, nor does it impose any constraint on the way they may interact (i.e. cooperate or compete)" (Hamdouch, 2010: 43). At the same time, a network is "a specific modality for the structuring or coordination of 
inter-organizational relationships among various legally independent actors (firms, entrepreneurs, institutions, etc.) aiming at achieving a common project in a specific domain through the control, exchange or sharing of information, know-how, knowledge, as well as products and/or capital". Those participating in a network may be co-located within the same cluster or belong to different clusters" (Depret and Hamdouch, 2011: 232).

These networking/clustering dynamics are mainly needed because the development of green technologies is constrained by several factors. Firstly, these technologies often require the constitution of a critical mass of knowledge, competences and human and financial resources. Secondly, they imply huge R\&D, production and commercialization costs (Grübler et al., 1999). Thirdly, clean technologies are subject to many barriers that render their development or dissemination particularly difficult (del Rio and Unruh, 2007). Lastly, green technologies usually require close coordination amongst a great number of heterogeneous and geographically dispersed actors. This coordination often goes through the formation of interest coalitions, vertical and horizontal partnerships, inter-organizational networks as well as social and political networks, etc. Hence, there is a crucial role played by the territorial and institutional settings (at various scales) in which clean technologies can better develop and disseminate. By favouring the emergence and development of viable green clusters, these settings help solving the constraints identified above while giving coherence and visibility to the activities and the actors involved within greentech innovation processes.

These "green clusters" (and the innovation networks they build on) appear to be highly concentrated geographically (and technologically) and, for the most part, at an early (even very early) stage of development (table II). This "emergent" character of most green clusters may be explained both by efficiency constraints (especially the need to reach a critical size) and historical factors (the "path-dependency" inherited from past industrial and institutional structures and choices).

The main (or most visible) clusters are located in certain US states and Canadian provinces, some major Japanese cities, certain regions of the EU (Germany and Scandinavia, in particular), and some Emerging Countries (notably China). They occur precisely in those territories where the public authorities (national, regional or local) adopt (with the support of a vast coalition of private stakeholders and institutions) an active approach to the long-term co-integration of environment policies and innovation policies (Depret and Hamdouch, 2009; Hamdouch and Depret, 2010). 
Table II - An overview of the location of the main "green clusters" in the world. Quadro II - Localização dos principais "clusters verdes" no mundo.

\begin{tabular}{|c|c|c|}
\hline \multicolumn{2}{|c|}{ Localization of key "Green Clusters" (non exhaustive list) } & Main sectors / competence fields \\
\hline \multirow{11}{*}{ USA } & $\begin{array}{l}\text { California (San Francisco, San Diego, Sacramento, Los } \\
\text { Angeles) }\end{array}$ & $\begin{array}{l}\text { Solar, Wind, Bio-fuels, Biomass, Materials, Recycling, } \\
\text { Water }\end{array}$ \\
\hline & Texas (Austin) & Clean Energies, Bio-fuels, Fuel Cells, Energy efficiency \\
\hline & $\begin{array}{l}\text { New England (Massachusetts, Maine, Vermont, New } \\
\text { Hampshire, Connecticut, Rhode-Island) }\end{array}$ & Bio-fuels, Fuel Cells, Solar, Wind, Geothermic Energy \\
\hline & New York & $\begin{array}{c}\text { Fuel Cells, Biomass, Wind, Solar, Materials, Energy } \\
\text { efficiency }\end{array}$ \\
\hline & Louisiana & Renewable Energies, Energy efficiency \\
\hline & Washington & Bio-fuels, Biomass, Water \\
\hline & Florida & \multirow{5}{*}{ Solar, Wind, Bio-fuels, Batteries, Biomass } \\
\hline & \begin{tabular}{|l|} 
Colorado \\
\end{tabular} & \\
\hline & Connecticut & \\
\hline & New Mexico & \\
\hline & Illinois & \\
\hline Canada & British Columbia & Hydrogen Fuel Cells \\
\hline \multirow{6}{*}{ Japan } & Kansai & $\begin{array}{l}\text { Recycling, Purification, "Green Products", } \\
\text { "Environmental Services" }\end{array}$ \\
\hline & Kyushu & $\begin{array}{l}\text { Waste Management, Recycling, De-pollution, } \\
\text { Eco-materials, Renewable Energies }\end{array}$ \\
\hline & Chugoku & \multirow{4}{*}{ Environment, Recycling, Energy } \\
\hline & Okinawa & \\
\hline & Aichi-Nagoya & \\
\hline & Kitakyushu & \\
\hline \multirow{11}{*}{ China } & Zhongguancun & $\begin{array}{c}\text { Environment, Renewable Energies, Transports, New } \\
\text { Materials }\end{array}$ \\
\hline & Dalian & Environment, Electric Car, Nuclear Power, Wind \\
\hline & Zhongshan & New Materials, Bio-fuels \\
\hline & Nanyang & Electric Car \\
\hline & \begin{tabular}{|l|} 
Changsha \\
\end{tabular} & \multirow{3}{*}{ Solar } \\
\hline & Jining & \\
\hline & Weifang & \\
\hline & Guizhou & Recycling \\
\hline & Xuzhou & Renewable Energies \\
\hline & \begin{tabular}{|l|} 
Fengxian \\
\end{tabular} & Environment \\
\hline & Guangzhou & New Materials, Environment, Energy \\
\hline \multirow{12}{*}{$\begin{array}{l}\text { European } \\
\text { Union }\end{array}$} & $\begin{array}{l}\text { Germany ( } 28 \text { federal kompetenznetze + many regional } \\
\text { clusters at the Länder level) }\end{array}$ & $\begin{array}{l}\text { Energy, Environment, Transports, Mobility, New } \\
\text { Materials, Chemicals }\end{array}$ \\
\hline & France (23 "Pôles de Compétitivité") & Environment, Energy, Transports, Bio-resources \\
\hline & Spain (Basque Country) & \multirow{9}{*}{ Clean Energies, Transports } \\
\hline & Italy (Trentin) & \\
\hline & Portugal (Norte Region) & \\
\hline & United Kingdom (Wales, East of England) & \\
\hline & Austria (Graz, Linz) & \\
\hline & Slovenia (Velenje) & \\
\hline & Hungary (Szeged, Gyöngyös) & \\
\hline & Finland (Vaasa, Kuopio, Lahti, Oulu, Helsinki, Uusimaa) & \\
\hline & Sweden (Stockholm, Malmö, Östergötland, Småland) & \\
\hline & \begin{tabular}{|l|} 
Denmark (Aalborg, Aarhus, Løgstør, Odense, Copenhagen) \\
\end{tabular} & Renewable Energies, Clean Technologies \\
\hline
\end{tabular}




\section{PUBLIC POLICIES TO PROMOTE ENVIRONMENTAL INNOVATION: SIX NATIONAL CONTRASTING CASE STUDIES}

The six countries examined here are amongst the most advanced or most active (in terms of activities and/or statements) in the field of environmental R\&D and innovation. We believe that they constitute a number of interesting, although not yet fully established and often imperfect, examples or "models" of the long-term development (for the first three examples) or not (in the case of France) of promising new sectors.

Due to space limitations, other countries which deserved to be used also as "models" have been left aside, especially Germany - (which in many respects is a model similar to Japan but more decentralised), Spain (a sort of "Southern Denmark" in terms of photovoltaic energy), the Netherlands (the equivalent of little "Lander" of Germany, but very successful in the co-integration of environment policies) or Great Britain (which is now very committed in attempting to catch up with leading countries, especially in offshore wind energy).

\section{The United-States: A decentralised yet coordinated dynamic approach}

As in many other fields, the United-States has taken the lead in environmental $\mathrm{R} \& \mathrm{D}$ and new technologies. In this regard, they benefit from a favourable "ecosystem" (scientific, economic and institutional) supported by great interest from the business world for green sectors and technologies and a particularly active policy implemented at different spatial scales, though some serious uncertainties and threats still lie ahead (table III).

Indeed, it is in the United-States that the recent effort for environmental R\&D is the most spectacular. In 2010, the Obama administration granted only $\$ 4.6$ billion for the funding of R\&D in the environment and energy fields (AAAS, 2010). By contrast in 2009, out of the $\$ 787$ million Recovery Act launched by the Obama administration between $\$ 66$ million and 112 million were devoted (to be spent up to year 2013) to R\&D investments, at the federal level, in the new technologies related to renewable energies and sustainable development (Robins et al., 2009; UNEP, 2010).

In reality, taking into consideration the decentralised governance of the R\&D public funding system in the US (OECD, 2008), the federal credits dedicated to the environment are much more significant. In fact, although the Environmental Protection Agency and the Department of Energy are traditionally very closely involved in financing environmental and energy R\&D, other independent agencies ( $N A S A, N a$ tional Science Foundation, Advanced Research Projects Agency-Energy, etc.) and many federal departments (Defence, Health and Human Services, Agriculture, Transport, Commerce via the National Oceanic and Atmospheric Administration, etc.) also develop and support specific or interagency programmes (AAAS, 2010).

At the same time, certain pioneering states are now heavily investing in the development of regional centres of environmental and energy excellence, both because they consider the "green economy" as an important source of growth and jobs, but also because they want to be more responsible and ambitious (than the 
federal state) in reducing greenhouse gas emissions. This is the case in California, which represents a fully-fledged green business development "model". Other American states (Texas, Massachusetts, New York, Washington, Colorado, Connecticut and New Mexico in particular) are also very active in the field, particularly (but not solely) through public-private partnerships and interregional initiatives (e.g. the Regional Greenhouse Gas Initiative, the Western Climate Initiative, the National Alliance of Clean Energy Business Incubators and the Northwest Energy Technology Collaborative). At the local level, many cities and counties display a remarkable degree of activism based on a policy of clustering and/or different measures.

At the industrial level in the United-States, many companies and entrepreneurs are literally in the fore-front of the growth of these sectors through sustained flows of investments, job creations and innovative projects, thanks to the very active support of "green investors" that are convinced that the development of the green business will offer tremendous opportunities of profit and growth.

Table III - The "American model" (and its States' variants and specific forms).

Quadro III -O "modelo americano" (e as suas variantes e formas especificas nos Estados Unidos).

Main Characteristics:

\begin{abstract}
A nearly unique set of permissive levers:
- A more belated commitment on the part of federal, regional and local administrations (compared with more pioneering countries in the field), but larger and more responsive, and now better coordinated than elsewhere - An "ecosystem" highly favourable to innovation and entrepreneurship: Prestigious universities closely involved in cleantech projects, research contracts, business plan contests (such as the California Clean Tech Open), etc.

- A prevailing "context" that is increasingly favourable to environmental protection and energy savings

- Strong links between researchers, entrepreneurs and investors (venture capital firms and business angels)

- A knowledge and competence base unique anywhere in the world

- Manpower trained and qualified in environmental professions

- Sector specialization centred geographically on certain states, but covering the complete range of "green technologies" at the national level

- The advanced and multi-scaled integration of public policies and the use of a complete range of tools available to decision-makers

- The existence of complementary industries (microelectronics, nanotechnologies, agro-biotechnologies, etc) and service activities (intellectual property, legal and technical expertise, etc.).

- The deregulation of the energy market and structural under-investment in energy infrastructures

- The "critical mass" of the local population

- Influential social networks promoting renewable energies and clean technologies (for example, the Coalition to Advance Sustainable Technology and the US Green Building Council)
\end{abstract}

- A new voluntarist Administration convinced by green growth perspectives

\title{
But still fragile and rather uncertain prospects:
}

- Political uncertainties vis-à-vis the still upcoming effects of the financial, economic and social crisis in the US, notwithstanding the international threatening challenges for the US current government

- The gigantic public and private debt and the real capacity (will?) to invest further in greentech

- "Bubble effects" in high-tech sectors: Will greentech escape the ICT and biotech preceding "syndromes"?

- "US greentech valleys": irresistibly moving to (or being taken over by) Asia?

- Persisting strong pressures and recent new activism of some influential industrial lobbies (especially oil and other carbon-intensive sectors, such as tobacco and health industries)

- Recent discovery of non-conventional gas and oil resources, and enduring huge impact of barrel price evolution on green investments 
For each spatial scale in question (federal, states, county, city), governments and various public agencies and authorities invest significant financial resources. They engage a large spectrum of measures and tools related both to environmental policies (taxes, incentives, regulations, etc.) and to innovation policies (business incubators, tax credits, etc.), as can be seen in Hamdouch and Depret (2010).

\section{Japan: A centralised but scalable model}

Since the Seventies, Japan has pursued an ambitious environmental innovation policy. Partly to reduce its dependence on oil, but also to identify promising new sectors capable of replacing traditional industries (Inoue and Miyazaki, 2008). That is why Japan decided to invest massively and primarily in the photovoltaic energy sector, in particular the Sunshine (1974), Moonshine (1978) and New Sunshine (1994) programmes run by the Ministry of International Trade and Industry, which has enabled companies like Sharp, Kyocera and Sanyo to become world leaders. This planned policy is based on a number of key measures (Beise, 2004): the financing of university and private R\&D programmes; financial and tax incentives to fit residential and professional buildings with photovoltaic (PV) cells; fitting government buildings with PV cells; the grid-connected photovoltaic installations; attractive feed-in tariffs; encouraging competition between producers; and stimulating exports to create a leveraging effect to widen the scope of the market and, therefore, to the benefit of Japanese producers.

This momentum was boosted by the ratification of the Kyoto protocol. This provided the background for the New Energy Act (1997), which included a series of measures to promote renewables (support for $\mathrm{R} \& \mathrm{D}$, tax incentives, subsidies, preferential loan rates, etc.). In May 2006, the METI (Ministry of Economy, Trade and Industry) went a step further with the "New National Energy Strategy" (METI, 2006a) focusing on four key areas: the energy efficiency of buildings, "new energies" (photovoltaic, wind, biomass), transport (ethanol and fuel cell-related initiatives) and nuclear energy. More recently, the government announced that it was going to inject $\$ 30$ billion over five years into research in "eco-innovations" as part of the Cool Earth - Innovative Energy Technology Program (METI, 2008). At the same time, the NEDO (New Energy and Industrial Technology Development Organization) - a METI independent agency with a $€ 1.33$ billion budget - finances numerous $\mathrm{R} \& \mathrm{D}$ projects (totalling $€ 662$ million) in the environment and energy fields (NEDO, 2007). Lastly, considerable effort has been put into financing seven innovation clusters specializing in environment-related issues (METI, 2006b; MEXT, 2006). These various programs benefit Japanese companies which are constrained by stricter environmental regulations and which are, in turn, more innovative than their foreign competitors.

This policy in favour of environmental innovations has recently benefited from a new breath thanks to the victory of the Japanese Liberal Party (Democrats) at the general elections of 2009. Indeed, the Japanese Democrats are promoting a "low 
carbon society" project considering the environment and energy as one of the six "strategic areas for growth" (strategy for becoming an environment and energy power through "green innovation") on which is founded the new Japanese industrial policy (METI, 2010). In this perspective, the Japanese administration has implemented a dedicated policy (National Strategic Projects Related to "green innovation") focusing on three key areas: the promotion of renewable energies (NEDO, 2010), the energetic efficiency of buildings and the development of new generation environmental innovations (NRC, 2010). More recently, the Fukushima tragedy has accelerated the implementation of this policy and started a concomitant quick and total withdrawal of Japan from nuclear power energy.

The key features of the "Japanese Model" are summarised in table IV.

Table IV - The "Japanese model".

Quadro IV-O "modelo japonês".

Main Characteristics:

\section{Key advantage levers:}

- A considerable and advanced effort on the part of the authorities, taken on gradually by industrialists

- Strong links between the worlds of research and industry

- A systematic search for synergies between several complementary technological fields (i.e. between different clean or green technologies, biotechnologies, new materials and nanotechnologies in particular)

- A high geographic concentration of efforts in a limited number of (7) clusters

\section{But some concrete potential weaknesses and threats:}

- A particular specialization in a growing (excessive?) number of potentially high-growth niche markets, but costly, contested and uncertain technological areas (photovoltaic energy, hydrogen and clean vehicles, biomass, etc.)

- Limited and gradual coordination, yet not always constant or effective, between environment policies and innovation policies - as demonstrated by the recent failure to develop a Japanese "Bio-fuel" industry

- Aging population and the possible declining purchasing power and financing resources for new technologies

- Coping with new Asian economic "challengers"

- Difficulty to access some key resources (cf. for example the recent stop in Chinese exportation of rare earths and metals to Japan)

\section{Denmark: A potential "mini California"?}

From the Seventies onwards, Denmark has been resolutely committed to wind energy (Garud and Karnø, 2003; Kamp et al., 2004; Buen, 2006; van der Vleuten and Raven, 2006; Agnolucci, 2007; Lewis and Wiser, 2007; Smit et al., 2007). Confronted with the two successive oil crises, which started to have a major impact on the economy and to the rise in unemployment rates and, at the same time, poorly endowed with own key energy sources, Denmark was urgently looking for developing renewable energy programmes that could sustain a new growth path for its economy.

It is in this context that the Danish Wind Power Programme (1976) and the Energieplan (1981) were started. However, as the results yielded by these programmes have been clearly below expectations, new more ambitious programmes 
and regulations have been engaged in the nineties, namely: the Energi 2000 programme (1990), the Wind Turbine Law (1992), the Energi 21 programme (1996), the Plan of Action for Offshore Wind Farms (1997), the deregulation of the electricity market (1999), etc. Following this new momentum given to the development, especially to wind energy, this industry grew rapidly and gained in maturity and size. As a result of this pioneering commitment in this sector, Denmark has become, and is still - despite its small size and limited budgetary scope - one of the world's wind energy key actors (especially with Vestas counting among the leading companies in the world).

This development was sustained by a combination of successive, but coherent policies. Until the late eighties, the Danish government mainly subsidised the investments (that were, at the time, both substantial with rather uncertain returns) needed for the implementation of wind farms. In the nineties, the public financial support was mainly oriented toward subsidising the production of wind electricity and the replacement of obsolete turbines. During the first decade of 2000, the Danish government has been furthering the connection of wind farms to the electric power networks and the price-competitiveness of wind electricity. Today, the Danish policy is targeting new additional goals: a greater involvement of the Danish environmental innovation networks in European research programmes; the strengthening of the international competitiveness of the Danish firms; the consolidation of R\&D efforts in the environment, and the promotion of "green entrepreneurship" (Danish Government, 2007, 2009). Following this strategy of increasing its competitiveness in environment sectors, Denmark recently announced the implementation of an Action Plan for Promoting Eco-efficient Technology with a $€ 165$ million budget. The goal is to double the share of renewable energies by 2025 , raising it to $30 \%$ of energy consumed...

To explain the success of the "Danish model" in the different environmental sectors (primarily the wind sector), several factors should be highlighted (table V). 
Table V - The "Danish model".

Quadro V-"O modelo dinamarquês".

Main Characteristics:

\section{Many strengths:}

A strong social, political and economic demand (supported by public opinion, the government, and by lobbies representing employers, the agricultural industry and anti-nuclear groups) for new job creating activities

A long-term planning that is at the same time:

- early and proactive, enabling Danish first-movers to clearly take the lead over their current key competitors;

- "ingenious" and pragmatic, since it is financed from relatively limited resources;

- gradual, i.e. based on an incremental learning process focusing on research, development and demonstration;

- centralised, but coordinated and designed to help local stakeholders (public services, local authorities, rural cooperatives, private establishments, entrepreneurs, etc.);

- founded on an advanced, continuous (despite changes in the political landscape) and flexible integration of policies in support of environmental sectors, in particular wind energy;

- focusing on stimulating demand as well as supply.

An established culture of compromise between the different "social" stakeholders and numerous public-private partnerships bringing together the government, businesses, research institutions and banks

A "national sector-based innovation system" that is:

- involving all innovation stakeholders in the sector: designers, producers and installers of turbines, customers, research institutions, electricity companies, etc.;

- founded on close collaboration upstream of the markets, through coalitions of interest (i.e. lobbies), cooperation and networks in order to champion the "profession" on one hand, and on the other to build and consolidate a major and globally-recognised "knowledge and skills base";

- based on a stimulating competitive environment downstream of the markets (particularly export markets).

A very internationally-oriented model: priority given to exports to the biggest growth markets (US in the mid-Eighties; Brazil, Russia, India and China in more recent years) and strong involvement in collaborative EU programmes

A focus on several key technologies: wind energy, and more recently (and to a lesser extent) biomass, wastewater recycling, energy efficiency, industrial biotechnologies, bio-fuels, hydrogen

\section{But some challenging weaknesses and threats:}

- Small domestic market (potential difficulty in engaging and amortizing investments in new generation cleantech)

- Narrow technological specialization (mainly wind energy)

- Growing pressure of major "players" (e.g. United States, Germany and Spain) and ambitious, powerful "newcomers" (e.g. China and India) in renewables 


\section{France: An "anti-model" despite a clear "voluntarist" approach?}

The French eco-industry market is one of the main world energy and environment markets. However, this apparent dynamism is deceptive and French companies remain almost completely absent from the clean technology and renewables sectors. This is quite paradoxical, as France does possess numerous assets, starting with the world leadership of its "national champions" in sectors such as water, waste and energy, the quality of its research institutions and its geography (under-exploited forests, high levels of sunshine, extensive seacoasts, etc.).

This paradoxical situation has recently led the French authorities to take measures to support green technologies within the "Grenelle de l'Environnement", launched as a model of political virtue. Indeed, the total public and private investments and the spillovers stemming from the "Grenelle" are estimated at $€ 400$ billion by 2020. The public effort devoted to this policy is substantial. It comes from the State (€26.3 billion), the various local and regional governments (€69.4 billion), and various other public institutions and agencies as well as State-owned enterprises (€37.3 billion) (CGDD, 2009).

However, this change of course is still hesitant and fragile especially in the very difficult current economic and financial climate, as demonstrated by the persistently half-hearted measures taken to promote environmental innovation and R\&D. These include only one billion euro invested over four years, $€ 400$ million of which for "new energy technologies" (second generation bio-fuels, the capture and storage of $\mathrm{CO}_{2}$, energy efficient buildings, etc.). Moreover, several key measures initially put forward in the first stage of the "Grenelle de l'Environnement" (such as taxing carbon emissions, tax cuts and subsidies in favour of the photovoltaic sector, withdraw regarding the idea of a preferential tax on value added for "ecological products", etc.) have been weakened at the implementation stage ("Grenelle de l'Environnement 2"').

All in all, France seems poorly prepared to profit from the enormous benefits the explosion of the 'Green Economy' appears to offer. Compared to the three previous examples, France is a sort of "anti-model", suffering from a series of errors and shortfalls (table VI). 
Table VI - The "French model".

Quadro VI-O "modelo francês".

\begin{tabular}{l}
\hline Main Characteristics: \\
\hline - Sotential advantages (Genuine "World-class" assets): \\
- Real "World Class" competences in water, nuclear power, waste management, energy efficiency, public \\
transports, urban design, etc. \\
- Geographical key advantages: large (underexploited) forests; many sunny and windy regions; wide double \\
seaside's; etc.
\end{tabular}

But too many enduring (yet voluntarily managed and sometimes relatively overcome) weaknesses and brakes:

- Belated efforts (mainly countercyclical), still underdeveloped (particularly in the private sector), or even of "eyewash" sort (announcement effects; burden put mainly on local governments, whose Financial resources are rather fragile; hope that a multiplying effect of public expenditure will be yielded by the private sector; etc.)

- Disciplinary compartmentalization of the various technological fields, the benefits of which are potentially linked to the environment (including when the innovation stakeholders involved are co-located or geographically close)

- Focus on first generation eco-technologies (end-of-pipe) rather than second generation eco-technologies (integrated)

- Overly dispersed R\&D resources and projects: for example, the "competitiveness (green) clusters"* policy. - Essentially "small-scale" nature of the policies deployed (i.e. not internationally-oriented enough, sometimes autarkic)

- Persistence of many institutional obstacles

- Inhibitive role of industrial lobbies (particularly the automotive, chemical and nuclear lobbies) and intermediaries (politicians, trade unions, and technocrats)

- Large number of, and lack of coordination between, different environmental innovation stakeholders: the "financiers" (different ministries involved [economy, industry and employment; ecology, energy, sustainable development and regional development; higher education and research; etc.], multiple agencies (in particular ADEME), and certain Regional Councils and the European Union) and those receiving finance (Centre National de la Recherche Scientifique, Commissariat à l'Energie Atomique, Institut Scientifique de Recherche Agronomique, University research laboratories, specialized industrial technical centres, industrial R\&D laboratories and consultancy and engineering companies)

- Absence of links, consistency and coordination between the environment policy (still too often essentially corrective) and the innovation policy (seen more as part of the higher education policy, or even a regional development policy, rather than as a real R\&D and entrepreneurship policy)

* No fewer than 23 of the 71 (!) "Pôles de Compétitivité" (competitiveness clusters) in France perform activities related to the environment, energy and transport. Unfortunately, none has been awarded the "superior" label of "world-class competitiveness cluster", while only four among them have an international scope and critical mass (see DATAR, 2010).

\section{South Korea: A "strong voluntarist", but pragmatic planning approach}

The commitment of South Korea to the green business is very recent. From 1990 to $2005, \mathrm{CO}_{2}$ emissions increased by more than 90\% (like in China), putting South Korea amongst the most energy intensive users of OECD countries (OECD, 2010). In 2005, South Korea decided to change this pattern; indeed it has been at the origin of the Seoul Initiative Network on Green Growth, which intended to promote 
an environmentally sustainable economic growth in the Asia and Pacific region (Jones and Yoo, 2010; OECD, 2010). However, it was not until 2008 that this initiative found its first concrete applications when the South Korean President (Lee Myung-bak) decided to engage in a vast plan labelled "Low Carbone, Green Growth". This plan's goal was to make South Korea a "low carbon society" based on a "green growth" strategy (Vilaihongs, 2009).

This National Strategy for Green Growth (2009) is in reality part of a wider framework aiming at putting R\&D and green growth at the heart of South Korean economic policy. Indeed, the objective of South Korean authorities is to invest nearly $5 \%$ of national GDP in R\&D (compared to $3.5 \%$ in 2007) through a yearly $10 \%$ increase in R\&D expenses from 2009 to 2012 (Vilaihongs, 2009). It is also in this perspective that South Korea has devoted about $80 \%$ (between $\$ 25$ billion and $\$ 38.5$ billion depending on the estimates) of its stimulus plan to green growth (Robins et al., 2009; UNEP, 2010).

More broadly, the South Korean Five-Year Plan for Green Growth (2009-2013) should translate into more than $€ 63.2$ billion of public investments, which corresponds every year to nearly $2 \%$ of GDP (Jones and Yoo, 2010). Within this framework, substantial investments (about $€ 7$ billion by 2013) are dedicated to the development of more ecological products and 27 green core technologies (solar batteries, GPL hybrid vehicles, LED technologies, etc.) (Vilaihongs, 2009; OECD, 2010). In total, the South Korean government and private companies (chaebols) respectively, should invest about $\$ 6.3$ billion and $\$ 29.7$ billion in renewable energies, by 2015 (Kang, 2010; Sojung, 2010). Most of this effort is oriented towards solar and wind energies ( $\$ 2.7$ billion of investments by 2015) and also offshore-wind development ( $\$ 8.1$ billion by 2019) (Kang, 2010). Through these substantial investments, the South Korean authorities are expecting to strengthen the competitiveness of their economy in this promising sector. Ultimately, the South Korean 2009-2013 plan is supposed to generate $€ 110$ billion to $€ 125$ billion of economic total spillovers and to create 1.56 to 1,81 million jobs by 2013 (Ojardias, 2010).

Along with this ambitious strategy, the South Korean government has implemented a series of incentives and measures supporting its green growth policy (Jones and Yoo, 2010; OECD, 2010). These include voluntary and negotiated agreement systems, energy efficiency programmes, renewable portfolio standards, clean development mechanisms and carbon markets, environmental taxes, emission trading systems and carbon taxes, environmentally harmful energy subsidies, R\&D in green technologies, green fiscal measures, information campaigns, the building of neutral-carbon footprint, State guaranteed loans, etc. Finally, a $€ 750$ million programme is devoted to the education and training of more than 100,000 "green collars" (Ojardias, 2010).

As such, the "South Korean Model" looks as a "hybrid" of political voluntarism, excessive centralisation and public-private partnerships, which explains its obvious advantages, but also its many structural weaknesses (table VII). 
Table VII - The "South Korean model".

Quadro VII-O "modelo Sul-coreano".

\begin{tabular}{l}
\hline Main Characteristics: \\
\hline Clear advantages: \\
- A National vision for the next 60 years (!) \\
- Focused measures supporting an ambitious strategy ("Creation of a New Green Korea") \\
- Substantial efforts (2\% of yearly GDP from 2009 to 2013) aimed at catching up with the green economy \\
leaders \\
- Large industrial groups ("chaebols", like Samsung, LG, KT) as key stakeholders of the South Korean "gre- \\
en new deal" \\
\hline But enduring structural weaknesses: \\
- Enduring protectionism; administrative brakes; weakness of the national electric infrastructure; strong \\
dependence of SMEs on chaebols and public aids; etc. \\
- High overseas dependence ( $97 \%$ ) on energy sources and relatively low energy efficiency in industries \\
- Opposition of NGOs to some measures of the Plan, e.g.: the project for the rehabilitation of four large rivers \\
and the subsequent construction of four tidal power stations; priority given to nuclear power in comparison to \\
other renewable energies; modest ambition regarding the reduction of $\mathrm{CO}_{2}$ emissions; etc. \\
- Mismatch between human resources and R\&D spending in Korean universities, and enduring weak collabo- \\
ration among universities, research centres and industrial companies \\
\hline
\end{tabular}

\section{China: A centralised "greening" at large scale}

During the last three decades, China has enjoyed unrecorded economic growth rates. However, this fast development has been accompanied by some severe problems: several ecological disasters (air, soil and water dramatic pollution rates); a strong dependence on fossil high-polluting energies (especially coal and oil); a tremendous waste or resources (very often due to obsolete infrastructures), etc. Indeed, since 1990, China has doubled its $\mathrm{CO}_{2}$ emissions and is today the most important "contributor" for greenhouse gas emissions as well as the leading world energy consumer.

Taking awareness of such an unsustainable development path and of the great dependence of the country on fossils ( 70 to $80 \%$ of total energy consumption, with coal, the most polluting one, accounting alone for $50 \%$ ), the Chinese government has recently decided to profoundly revise and recast the long-term very foundations of its development. Accordingly, the Chinese authorities placed clean technologies and renewable energies amongst their key strategic orientations in the last two 5-year plans, very much at the heart of their legislative priorities.

The 11th 5-year Plan (2006-2010) targeted a "harmonious society" based on a more sustainable use of resources and a better care of the environment. This plan was breaking away from the 1980's and 1990's plans that were essentially focused on economic growth and the development of the industry and agriculture. For the first time in the contemporary history of China, the 11th Plan explicitly stated environmental objectives aimed at reducing the energetic intensity of the country (Barreau and Buba, 2009). Even if it will not be publicly available before March 2011, the 
12th 5-year Plan (2011-2015) is likely to follow suit, and may even consolidate the new orientations put forward in the previous one. It should notably accentuate the direct investments devoted to renewable energies, "clean coal", electric infrastructures and "green cars". According to certain sources, it amounts to $\$ 575$ billion of total investment over 10 years (Torgemen, 2010).

In line with new orientation, China has devoted a substantial share of its stimulus plan to green growth ( $\$ 221.3$ billion over 2 years ${ }^{\mathrm{ii}}$ ) and specifically to renewable energies (Robins et al., 2009). In addition, within the period 2005-2009, almost $\$ 79$ billion have been invested both by the Chinese government and the private sector in renewable energies and energy efficiency (UNEP, 2010). Since 2009, China has become the leading "player" in this field (ahead of the United-States), particularly in wind energy ( $81 \%$ of Chinese investments in renewables and energy efficiency; $40 \%$ of total world investments in wind energy). In the same vein, $\$ 1.5$ billion has been invested for supporting research into clean cars (Brière, 2010).

Along with these plans, stimulus policy and specific programmes, China has also deployed a new jurisdictional/ fiscal real "arsenal" supporting green growth. Indeed, the country adopted in 2005 a law on renewable energies (which was reinforced by a new law in 2007) comprising ambitious, new legal mechanisms and incentive tools (especially at the fiscal and financial level) that have already proved to be relatively efficient (Junfeng et al., 2010). The National Climate Change Programme launched in 2007 also marked a key step in the Chinese environmental policy (Barreau and Buba, 2009). Finally, other laws (particularly the Cleaner Production Promotion Law and the Environment Impact Assessment Law in 2003) and numerous legal devices (eco-taxes, fiscal incentives, etc.) complete the system (Wang, 2010).

At the local level, the provinces and the metropolitan governments also play a key role (Junfeng et al., 2010), particularly in the constitution of green clusters (Wang, 2010). However, if this green growth strategy, as applied at the regional and local scale, yield a certain "multiplying effect" of centrally-decided investments, it also often translates into the emergence (sometimes artificially) of "local champions" (Brière, 2010), the waste of resources (notably financial ones but spreading them over a great number of competing projects lacking of minimal critical size; see also the French case above for a similar problem) and the development of oversized industrial capacities.

Nevertheless, and all related matters considered, China is already the second "post-carbon and environmental goods and services market" (after the United-States) with a turnover estimated at $\$ 675$ billion, corresponding to $13.5 \%$ of world market share in 2007-2008 (BERR, 2009). The Chinese market could even grow beyond $\$ 1,000$ billion by 2013 (China Greentech Initiative, 2009). Equally, China has now several world leaders in the 'green business' (Suntech, Yingli, Trina Solar and Solarfun in the photovoltaic industry; Sinovel, Goldwind and Dongfang in wind energy, etc.), while other Chinese companies are likely to play an increasing role in the next few years (BYD, SAIC Motor, Chery Automobile or Geely Auto in electric and hybrid cars or in fuel-cells; DEC, Windey or Sewind in the wind energy industry, 
etc.). These companies benefit from the direct and indirect support of the Chinese public authorities (and from the various instruments promoting green growth policy), but also from an almost unbeatable price-competitiveness advantage, and, last but not least, from the technological transfers stemming from their competitors/ "partners" (Brière, 2010).

In line with this irresistible trend, is also in China where stock market new listings have been the most important in the world in 2009 (UNEP). Equally of major importance have been venture capital investment growth rates, reaching $€ 350$ million in 2009 (CVCRI, 2009; Wang, 2010). Finally, the Clean Development Mechanism launched after the Kyoto Protocol has also benefited Chinese companies, which have been able to capture nearly half of the carbon emission credits allowed by the United Nations Framework Convention on Climate Change (Brière, 2010).

Summarising, the "Chinese Model" is truly a puzzling one: it resembles a centrally orchestrated "take-it-all" bulling ("pragmatic" or even "opportunistic") strategy, based on many concrete levers and substantial means, but that is (still) displaying several weaknesses, difficulties and uncertainties (table VIII).

Table VIII - The "Chinese model".

Quadro VIII - O "modelo chinês".

\footnotetext{
Main Characteristics:

A set of obvious levers and key "master cards" at the global level:

- The first market in the World (in terms of consumers number, but also probably in value in the future)

- A late, but strong and continuous public commitment in green economic development

- Substantial (unlimited?) financial resources

- Tremendous needs (especially in renewables energies)

- A growing leadership in renewables

- A quasi-monopoly in rare earths (minerals that are indispensable in the production of some key components used in renewables technologies)

- An "institutionalised protectionism" that persists despite real progress (cf. for example the Renewable Energy Law, repealed in 2009, which was imposing, among other things, that $70 \%$ of the components of a wind turbine installed in China should be produced in the country)

\section{But enduring serious weaknesses and difficulties:}

- Structural weaknesses in R\&D (despite a real effort of catching-up), particularly within the private sector

- Several gaps between ambitious announces and concrete implementation policies (certain projects are resembling genuine "Potemkin Villages")

- A fragmentation of the market among (too) numerous actors

- An enduring resource misuse at the local level

- A development pattern that remains mainly "quantitative" (emphasis on price-competitiveness, low quality) rather than "qualitative" (based on radical innovation)

- Electricity delivery infrastructures and networks that lag behind the rapid growth on new (renewable energies) facilities

- A dramatic shortage of skilled manpower (even if the situation improves, but rather too slowly as the needs are literally gigantic)

- A lack in human competences of certain central administrations (notably in the Ministry of Environment protection) and at the local level
} 


\section{PUBLIC POLICIES, TERRITORIAL SPECIFICITIES AND THE DEVELO- PMENT OF THE "GREEN ECONOMY”}

Based on the developments outlined above, and the case studies in particular, it is possible to identify three series of conclusions and analytical observations that enlighten our thinking on this subject.

\section{Policy features: Lessons from leading "Green Economy" countries or regions}

From the cases described above, it seems quite clear that leading "Green Economy" countries or regions share most of the following, key characteristics:

- They demonstrate a strong political commitment (including in countries characterized by liberal economic traditions)...

- ... these often translate (when green technologies and activities require costly investments) into important efforts (in human and financial terms) over the long-term in the R\&D and environmental innovation fields. This commitment is sometimes merely oriented toward facilitating the networking of actors; this is usually the case when the green activities do not require too high public and/or private investments. More rarely, specific policies in favour of green entrepreneurship and SMEs are also engaged (Hamdouch and Depret, 2013).

- They have used different tools or mechanisms (not necessarily financial) related to various policies dedicated to innovation, the environment, transports, energy, building and housing, spatial planning and territorial development, even to agriculture, education, entrepreneurship, etc.

- They engage these policies at different spatial scales (national, regional or local).

- They are in general fairly responsive, pragmatic and/or flexible in their approach.

- They understand that they are committed to a process requiring a high degree of involvement over long periods with a large number of closely interlinked stakeholders (including firms and private investors).

- They benefit from (or were able to create) an "ecosystem" particularly favourable to the emergence, development and dissemination of radical environmental innovations.

- They tend to specialize in a single (or a few) "green sector(s)" in which they become, in the long run, the, or one of the leader(s).

- They intervene on the supply side by creating an ecosystem favourable to green enterprises, but also on the demand for clean products/services/processes/energies by implementing regulations and incentives (environmental standards, ecologically-based fiscal cuts vs. penalties, recycling constraints, information campaigns, etc.) aimed at changing consumer behaviour and 
households' way of life because these countries are aware that the "green economy" will probably need much more social, cultural and political experiences.

This empirical observation is supported by at least three main and closely interrelated arguments. Firstly, environmental innovations require the development of a "critical mass" of knowledge, skills and resources (particularly in financial and human terms), at a global (or continental) level to cover the significant R\&D, production, and marketing costs (Grubb, 2004). Secondly, there are many economic and extra-economic barriers to the adoption of these innovations (technical/marketing, regulatory and administrative uncertainties; the lock-in risk; sometimes excessive hidden costs; high training and experimental costs, etc.), which tend to impede their "natural" dissemination (del Rio and Unruh, 2007; Lewis and Wiser, 2007; Foxon and Pearson, 2008; Luken and Van Rompaey, 2008). Lastly, these innovations require the effective coordination (through coalitions of interest, partnerships, social networks and clusters) of a large number of heterogeneous (from an organizational and/or cognitive point of view) and geographically dispersed actors (Jacobsson and Johnson, 2000; Christiansen and Buen, 2002; Grubb, 2004; Steurer, 2007; Barreto and Kemp, 2008).

For all these reasons, the effective development and dissemination of environmental innovations is facilitated when these innovations have initially been developed on a lead market before gradually supplying "peripheral" markets (Cowan and Hultén, 1996; Jacobsson and Johnson, 2000; Christiansen and Buen, 2002; Jacobsson and Bergek, 2004; Wietschel and Seydel, 2007; Barreto and Kemp, 2008; Foxon and Pearson, 2008). Hence, to establish and sustain such a market, some "protection" (at least in the early stages) of domestic firms is generally needed (Kemp et al., 1998; Beise and Rennings, 2005; Ömer-Rieder and Whitelegg, 2005; Hendry et al., 2007; Nill and Kemp, 2009).

In this perspective, adapted innovation policies, regional development policies and environment policies must combine efficiently (Jänicke, 2008; Hamdouch and Depret, 2010), for a convergent analysis applied to regional development, see e.g. Pessoa and Rui Silva (2009). Indeed, the former are crucial in supporting the emergence and industrial taking-off of green innovations, while at the same time the latter, by providing clear orientations and incentives in favour of the environment, attenuate the uncertainties and therefore encourage the various stakeholders to invest in green technologies and activities. On the other hand, when the innovation policies are underdeveloped or insufficiently adapted, they are often incapable of promoting truly innovative environmental activities, or even contribute to "nipping in the bud" certain otherwise "sustainable" industries. This is especially true when, at the same time, incentive measures pertaining to the environment policy are insufficient or non-existent (for example, the development of solar and wind energy in France).

This dynamics is well documented for a large number of sectors (in many countries), including: wind and solar energies, particularly in Europe (Denmark, Norway, 
Sweden, Germany, Spain, Great Britain, the Netherlands), the US (Christiansen and Buen, 2002; Garud and Karnøe, 2003; Buen, 2006) and Japan (Garud and Karnøe, 2003; Beise and Rennings, 2005); bio-fuels in Europe (Bomb et al., 2007); electric cars in the US and Europe (Cowan and Hultén, 1996); hydrogen and fuel cells, particularly in the US, Canada, Japan, Germany and Great Britain (Hall and Kerr, 2003; Brown et al., 2007; Wietschel and Seydel, 2007); etc.

However, the simple combination (or integration) of policies is not sufficient in itself. It also requires a strong and lasting coordination over time of the policies that are engaged. Otherwise, it is likely to yield only limited effects or worse, it may well simply fail (as happened recently regarding the development of a bio-fuels' industry in Japan). In fact, as we will now see, the co-integration of policies requires certain time-space conditions.

\section{Policy co-integration and the conditional development patterns of the "Green Economy"}

Although combining measures derived from environment, innovation and regional development policies appears to be effective, it still seems that the choice of measures to be implemented is less important than their respective proportion and above all their timing and their territorial deployment (Hamdouch and Depret, 2010).

The long-term and territorial co-integration of public policies is to a great extent contingent in nature. This is especially due to the various uncertainty sources that may affect each of the policies' effectiveness. Institutional factors that shape consumers and investors' behaviour, as well as many demand and supply factors (economic financial, scientific, technological, social, etc.) are susceptible to weaken policies' expected effects. Not only do these various factors combine (Grubb, 2004; Kivimaa, 2007), but also, and more fundamentally, they induce one another and therefore co-evolve alongside each other within a time-space dynamics that is specific to a certain territorial setting (Depret and Hamdouch, 2007; 2009).

That is why the factors impacting the launch and/or development of innovation processes in the environmental field often differ from one "clean" technology to another and/or from one "green" sector to another, from one period to another and often from one city, region or country to the other (for example the case of the differentiated development paths of the fuel-cells market respectively in Germany, Great-Britain, Japan and the United-States according to Brown et al., 2007]). This is particularly true given that the choice and timing of the measures to be taken also depend on the nature of the environmental innovations in question (and their existing or potential alternatives), and on their stage of development and scope for application.

This being the case, advanced co-integration strategies of public policies to promote environmental innovations and sectors are often circumstantial (i.e. adapted to the "green" sector or to the "clean" technology in question, and to the prevailing 
"context"). These strategies need to be multi-scalar in nature (i.e. adapted to targeted geographic areas), trans-sectoral, multi-actor, sustainable (designed in a mid to longterm perspective) and gradual (i.e. evolving over time). Hence, co-integration strategies require time, reactivity and pragmatism (see the notion of "time-strategic evolutionary policy" proposed by Nill and Kemp, 2009). It also supposes a mix of "ingeniousness" (especially when there is a lack in resources) and improvisation (see the notion of "bricolage" [sic] proposed by Garud and Karnø [2003]). This policy is therefore subject to a learning process through "trials and errors" (Kamp et al., 2004), a process within which the actors' respective vision, actions and practices adapt and co-evolve one with each other (Kemp et al., 2007). Finally, this co-integration of public policies in the environmental field is usually implemented both in upstream markets ( $R \& D$ programmes, technology valorisation and transfer programmes, formation of "green clusters", education and training of a professional manpower in environmental fields, etc.) and downstream (favouring vertical and horizontal linkages among related activities within a technological or industrial field, guaranteeing prices or tariffs, facilitating the access to financial and capital markets, stimulating effective rivalry among suppliers, etc.).

Finally, the strategic objective of these policies is to render the socio-economic and institutional "context" as propitious as possible for the domestic companies involved in environment activities, and therefore to create and/or consolidate a real "competitive advantage" in certain key sectors (similarly to what has been achieved by Denmark in wind energy).

\section{The co-existence of different "models"}

The dynamics of the emergence, development and structuring of new green sectors does not correspond to a unique or universal "model". In fact, although they have a lot in common, the cases outlined above differ, in our view, according to three structuring dimensions:

i) The degree of co-integration of environment, innovation, regional development and other policies;

ii) The resources (human and financial) that the (public and private) stakeholders are capable of investing to promote environmental innovations and/or sectors;

iii) The responsiveness, pragmatism and flexibility of the various stakeholders.

Based on these three dimensions, we believe that it is possible to outline a basic typology of these dynamics to reveal (among others) at least six generic "models" - corresponding to the US, Japanese, Danish, French, South Korean and Chinese examples - each with their own characteristics and developmental approach (table IX and fig. 1). 
Table IX - Characteristics of the main "models" of emergence, development and structuring of "green" sectors.

Quadro IX-Características dos principais "modelos" de criação, desenvolvimento e estruturação de sectores "verdes".

\begin{tabular}{lccc}
\hline & $\begin{array}{c}\text { Co-integration } \\
\text { of public policies } \\
\text { (non-existent to high) }\end{array}$ & $\begin{array}{c}\text { Financial resources } \\
\text { invested } \\
\text { (limited to ample) }\end{array}$ & $\begin{array}{c}\text { Responsiveness, pragmatism and } \\
\text { flexibility of stakeholders } \\
\text { (poor to excellent) }\end{array}$ \\
\hline USA & ++ & +++ & ++ \\
Japan & + & ++ & - \\
Denmark & +++ & -- & +++ \\
France & + & - & -- \\
South Korea & ++ & +++ & + \\
China & +++ & +++ & +++ \\
\hline
\end{tabular}

Financial resources invested

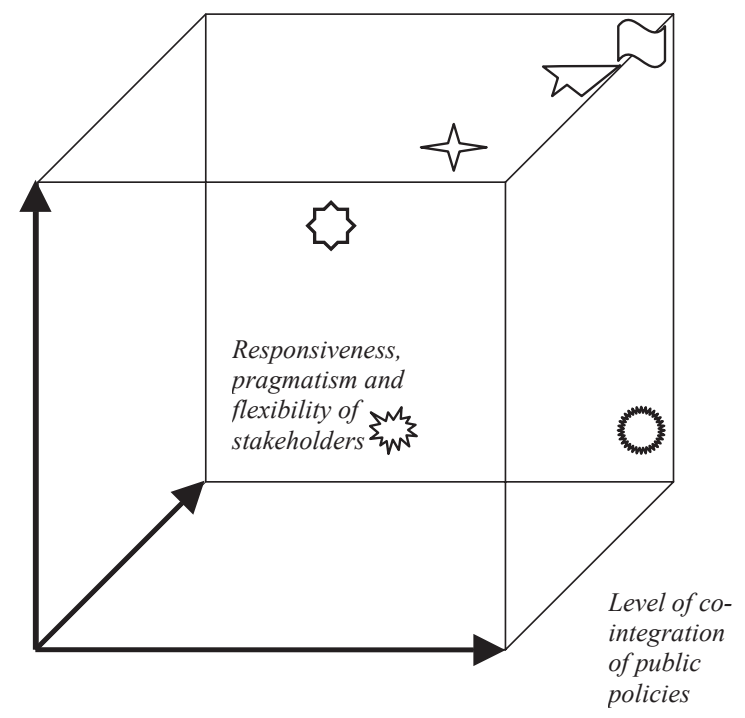

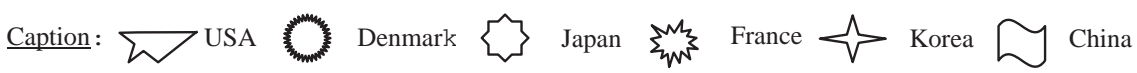

Fig. 1 - A 3D mapping of the main "models".

Fig. 1 -Representação tri-dimensional dos "modelos" principais.

\section{CONCLUDING REMARKS}

The aim of this paper was to investigate the way sustainable development challenges and constraints can give rise to a voluntarist environment, innovation and industrial public policies favouring the development of new green technologies and activities. However, as argued from a broad perspective and illustrated in the national 
case studies examined, some key conditions are required for eventually making such policies successful. Among several other "ingredients", policy integration strategies and inter-temporal and multiscalar coherence in policy orientations and measures appear to be particularly crucial components in such dynamics. These components and their effectiveness depend on various contextual and institutional factors that appear to be highly specific to each territory considered, be it a country or a region. Indeed, the ability of a given territory to develop a sustainable growth-path for green innovation and environment-based activities relies heavily on the historical, socio-economic, political, entrepreneurial and cultural settings in which policies have been designed and implemented (i.e. on path-dependent factors), as well as on a genuine political voluntarism, on policy adaptation and coherence, and on the collective/ cooperative commitment of the various stakeholders vis-à-vis the environment and green activities development (i.e. on path-creative moves).

Yet, as useful and encouraging as they may be, the analytical and empirical observations made in this exploratory paper require further research efforts. Indeed, a more extensive and in-depth examination of the territorial dynamics of the emergence, structuring (into clusters and innovation networks in particular) and development (in space and time) of new environment-related sectors is now required. The setting up of this programme of theoretical and empirical research should, we believe, be based on an examination of at least four complementary areas.

Firstly, it is essential to produce a more systematic and detailed account of the complete range of measures and means used to support policies (at national and local levels) aimed at promoting green innovations and sectors. In this regard, it is particularly important to explore the question of the nature, consistency, levels of co-integration, coordination (between the different spatial scales and among stakeholders) and the timing of these different measures. It is also necessary to explore the existence (or otherwise) of other geographic and/or sector-based "models" (or "anti-models").

Secondly, as radical environmental innovations (especially in clean technologies and environmental services) are more likely to result in the development of new, substantial and competitive green sectors (Depret and Hamdouch, 2009) than mere incremental innovations - a more in-depth analysis of the determining factors and approaches impacting within specific territorial settings should be performed. In addition, the technological and industrial dynamics of such innovations and the resulting economic activities should also be analysed. This task is inescapable if one wants to understand why certain radical environmental innovations develop more or less rapidly (depending on the development stage of the supporting technologies and their markets), and why this development appears within certain territories rather than in others. From this perspective, it may be helpful to compare, for example, the developmental paths of the techno-industrial dynamics of techniques relating to the capture and storage of $\mathrm{CO}_{2}$ (experimental technologies and non-existent markets), fuel cells (unstable technologies and embryonic markets), photovoltaic cells or electric cars (developing technologies and niche markets) and wind energy (mature technologies and high-growth markets). 
Thirdly, as in-depth territorial case studies of the development of green sectors are still in their infancy, a major effort of empirical work on this factor is still needed. This work is required not only for understanding, on a comparative base, the very territorial dynamics at work in the environmental field, but also for better mapping the places (regions, cities, clusters, etc.) where such development occur to a larger extent than elsewhere. If sustainable development challenges call for the creation and dissemination of new clean technologies (more broadly, environmental innovations and green sectors), and if these technologies and innovations are to become, as some believe or hope, a new "green gold" and the key basis for future growth, job creation and competitiveness, then there obviously must be better or more promising "terrain" configurations and "mine sourcing" within specific environments.

Finally, one may question the "sustainability" of the co-integration policies engaged in the environmental field over the last few years in the light of more recent changes. In particular, the restrictive budgetary policies engaged (especially in Europe) since the starting of the financial crisis in 2008 constitute a kind of "stress test" for green growth policies (Crassous-Doerfler, 2011). One can also wonder if the development of policies favouring clean technologies and renewable energies could highlight questions regarding the actual modes of production and consumption based on an extensive use of carbon and its derivatives or if these policies are rather a mere means for exploiting before others market niches that seem to be promising in the future.

\section{ACKNOWLEDGMENTS}

The authors would like to thank the two anonymous referees of the journal, whose detailed remarks and suggestions helped them greatly in refocusing and improving the initial version of this paper. The usual caveats apply.

\section{BIBLIOGRAPHY}

AAAS (2010) AAAS report XXIII: research \& development FY 2010. American Association for the Advancement of Science, Washington D.C.

Agnolucci P (2007) Wind electricity in Denmark: a survey of policies, their effectiveness and factors motivating their introduction. Renewable and Sustainable Energy Reviews, 11(5): 951-963.

Barreau B, Buba J (2009) La Chine dans le processus de Copenhague: la difficile inclusion d'un grand émergent. In Tirole J (ed.) Politique climatique: une nouvelle architecture internationale. Centre d'Analyse Stratégique, Paris: 225-240.

Barreto L, Kemp R (2008) Inclusion of technology diffusion in energy-systems models: some gaps and needs. Journal of Cleaner Production, 16(1), Supplement 1: 95-101.

Beise M (2004) The international adoption of photovoltaic energy conversion: is Japan a lead market? Discussion Paper Series, 153, Kobe University.

Beise M, Rennings K (2005) Lead markets and regulation: a framework for analysing the international diffusion of environmental innovations. Ecological Economics, 52(1): 5-17.

Berkhout F (2002) Technological regimes, path dependency and the environment. Global Environmental Change, 12(1): 1-4.

BERR (2009) Low carbon and environmental goods and services: an industry analysis. BERR Department for Business Enterprise \& Regu- 
latory Reform, John Sharp Innovas Solutions Ltd, Winsford Cheshire.

Bomb C, McCormick K, Deurwaarder E, Kåberger T (2007) Biofuels for transport in Europe: lessons from Germany and the UK. Energy Policy, 35(4): 2256-2267.

Bonini S M J, Oppenheim J M (2008) Helping 'Green' Products Grow. The McKinsey Quarterly, October.

Brière H (2010) Le business vert en Chine: quelles réalités. Accomex, 91: 21-24.

Brown J, Hendry C, Harborne P (2007) An emerging market in fuel cells? Residential combined heat and power in four countries. Energy Policy, 35(4): 2173-2186.

Buen J (2006) Danish and Norwegian wind industry: the relationship between policy instruments, innovation and diffusion. Energy Policy, 38(18): 3887-3897.

CGDD (2009) Rapport annuel au Parlement sur la mise en ouvre des engagements du Grenelle Environnement. Commissariat Général au Développement Durable, Ministère de l'Écologie, de l'Énergie, du Développement durable et de la Mer, Paris.

China Greentech Initiative (2009) The China Greentech Report 2009. China Greentech Initiative, Shanghai.

Christiansen A C, Buen J (2002) Managing environmental innovation in the energy sector: the case of photovoltaic and wave power development in Norway. International Journal of Innovation Management, 6(3): 233-256.

Cooke P (2010) Jacobian cluster emergence: wider insights from 'Green Innovation' convergence on a schumpeterian 'failure'. In Fornahl D, Henn S, Menzel M-P (eds.) Emerging clusters: theorical, empirical and political perspectives on the initial stage of cluster evolution. Edward Elgar, Cheltenham: 17-42.

Cowan R, Hultén S (1996) Escaping lock-in: the case of the electric vehicle. Technological Forecasting and Social Change, 53(1): 61-79.

Crassous-Doerfler R (2011) La rigueur budgétaire: un «stress-test» pour les politiques de croissance verte? In Baron R, et al. (dir.) Le financement de la croissance verte, Conseil Economique pour le Développement Durable, Paris: 109-113.

CVCRI (2009) China Venture Capital Yearbook 2009. China Venture Capital Research Institute, Hong Kong.
Danish Government (2007) Danish Solutions to Global Environmental Challenges: The Government's Action Plan for Promoting Ecoefficient Technology. Ministry of the Environment, Copenhagen, July, 64.

Danish Government (2009) Agreement on Green Growth, Ministry of the Environment. Ministry of the Environment, Copenhagen.

DATAR (2010) La carte des pôles de compétitivité (CIADT du 11 mai 2010). Délégation interministérielle à l'aménagement du territoire et à l'attractivité régionale, Paris. http://www. datar.gouv.fr/IMG/Fichiers/201005_Poles_ competitivite_CIADT.pdf

del Rio P, Unruh G (2007) Overcoming the lock-out of renewable energy technologies in Spain: the cases of wind and solar electricity. Renewable and Sustainable Energy Review, 11(7): 1498-1513.

Depret M-H, Hamdouch A (2012) Clean technologies and perspectives of the green economy in emergent and developing countries: foundations, opportunities and constraints. In Laperche B, Levratto N, Uzinidis D (eds.) Crisis, innovation and sustainable development. The ecological opportunity, Edward Elgar, Northampton (MA): 259-284.

Depret M-H, Hamdouch A (2011) Multiscalar clusters and networks as the foundations of innovation dynamics in the biopharmaceutical industry. Région et Développement, 33: 227-268.

Depret M-H, Hamdouch A (2010) Développement durable, innovations environnementales et green clusters. In Zuindeau B (ed.) Développement durable et territoire, Presses Universitaires du Septentrion, Lille: 143-153.

Depret M-H, Hamdouch A (2009) Quelles politiques de l'innovation et de l'environnement pour quelle dynamique d'innovation environnementale? Innovations - Cahiers d'Economie de l'Innovation, 29: 127-147.

Depret M-H, Hamdouch A (2007) Changements technologiques, logiques institutionnelles et dynamiques industrielles: esquisse d'une approche co-évolutionnaire appliquée à l'industrie pharmaceutique et aux biotechnologies. Innovations - Cahiers d'Economie de l'Innovation, 25: 85-109.

Elzen B, Geels F W, Green K (eds.) (2004) System innovation and the transition to sustainability: theory, evidence and policy, Edward Elgar, London. 
Foxon T J, Pearson P (2008) Overcoming barriers to innovation and diffusion of cleaner technologies: some features of a sustainable innovation policy regime. Journal of Cleaner Production, 16(1-1): 148-161.

Foxon T J, Kohler T J, Oughton C (eds.) (2008) Innovation for a low carbon economy: economic, institutional and management approaches. Edward Elgar, London.

Garud R, Karnøe P (2003) Bricolage versus breakthrough: distributed and embedded agency in technology entrepreneurship. Research Policy, 32(2): 277-300.

Grubb M (2004) Technology innovation and climate change policy: an overview of issues and options. Keio Economic Studies, 41(2): 103-132 .

Grubb M, Jamasb T, Pollitt M G (eds.) (2008) Delivering a low-carbon electricity system: technologies, economics and policy. Cambridge University Press, Cambridge.

Grübler A, Nakicenovic N, Victor D G (1999) Dynamics of energy technologies and global change. Energy Policy, 27(5): 247-280.

Hall J, Kerr R (2003) Innovation dynamics and environmental technologies: the emergence of fuel cell technology. Journal of Cleaner Production, 11(4): 459-471.

Hamdouch A (2010) Conceptualizing innovation clusters and networks. In Laperche $\mathrm{B}$, Sommers P, Uzunidis D (eds.) Innovation clusters and networks, Peter Lang, Brussels: 21-63.

Hamdouch A, Depret M-H (2013) Green business and entrepreneurship. In Carayannis $\mathrm{E} \mathrm{G}$, Dubina I N, Seel N, Campbell D F J, Uzunidis D (eds.) Encyclopaedia on creativity, invention and entrepreneurship, Springer, New York, forthcoming.

Hamdouch A, Depret M-H (2010) Policy integration strategy and the development of the "Green Economy": foundations and implementation patterns. Journal of Environmental Planning and Management, 53(4): 473-490.

Hendry C, Harborne P, Brown J (2007) Niche entry as a route to mainstream innovation: learning from the phosphoric acid fuel cell in stationary power. Technology Analysis and Strategic Management, 19(4): 403-425.

IEA (2008) Deploying renewables: principles for effective policies. International Energy Agency, OECD Publishing, Paris.
Ingham M, Depret M-H, Hamdouch A (2011) L'innovation responsable comme opportunité stratégique: problematisation et illustration dans le cas de PME de la domotique. In Hamdouch A, Reboud S, Tanguy C (eds.) PME, dynamiques entrepreneuriales et innovation, Peter Lang, Brussels: 381-403.

Inoue Y, Miyazaki K (2008) Technological innovation and diffusion of wind power in Japan. Technological Forecasting and Social Change, 75(8): 1303-1323.

Jacobsson S, Bergek A (2004) Transforming the energy sector: the evolution of technological systems in renewable energy technology. Industrial and Corporate Change, 13(5): 815-849.

Jacobsson S, Johnson A (2000) The diffusion of renewable energy technology: an analytical framework and key issues for research. Energy Policy, 28(9): 625-640.

Jänicke M (2008) Ecological modernisation: new perspectives. Journal of Cleaner Production, 16(5): 557-565.

Johnstone N, Hašcic I, Kalamova M (2010) Environmental policy design characteristics and technological innovation: evidence from patent data. OECD Environment Working $\mathrm{Pa}$ pers, OECD Publishing, Paris, ENV/WKP, 16(2): 27.

Jones R S, Yoo B (2010) Korea's green growth strategy: mitigating climate change and developing new growth engines, OECD Economics Department Working Papers, $\mathrm{n}^{\circ}$ 798, OECD Publications, Paris.

Junfeng L, Pengfei S, Hu G (2010) 2010 China wind power outlook. Greenpeace China-CREIAGWEC, Beijing-Brussels.

Kamp L M, Smits R E H M, Andriesse C D (2004) Notions on learning applied to wind turbine development in the Netherlands and Denmark. Energy Policy, 32(14): 1625-1637.

Kang S (2010) South Korea to Spend \$36 Billion on Clean Energy by 2015 to Gain Markets. Bloomberg (12/10/2010) (http://www.bloomberg.com/news/2010-10-13/south-korea-tospend-36-billion-on-clean-energy-by-2015to-gain-markets.html).

Kemp R, Schot J, Hoogma R (1998) Regime shifts to sustainability through processes of niche formation: the approach of strategic niche management. Technology Analysis and Strategic Management, 10(2): 175-195. 
Kemp R, Totmans J, Loorbach D (2007) Assessing the dutch energy transition policy: how does it deal with dilemmas of managing transitions? Journal of Environmental Policy and Planning, 9(3): 315-331.

Kern F, Smith A (2008) Restructuring energy systems for sustainability? Energy transition policy in the Netherlands. Energy Policy, 36 (11): 4093-4103.

Kivimaa P (2007) The determinants of environmental innovation: the impacts of environmental policies on the nordic pulp, paper and packaging industries. European Environment, 17(2): 92-105.

Kivimaa P, Mickwitz P (2006) The challenge of greening technologies - environmental policy integration in finnish technology policies. Research Policy, 35(5): 729-744.

Lehmann M, Christensen P, Thrane M, Jørgensen T $H$ (2009) University engagement and regional sustainability initiatives: some danish experiences. Journal of Cleaner Production, 17(12): 1067-1074.

Lewis J I, Wiser R H (2007) Fostering a renewable energy technology industry: an international comparison of wind industry policy support mechanisms. Energy Policy, 35(3): 1844$-1857$.

Luken R, Van Rompaey F (2008) Drivers for and barriers to environmentally sound technology adoption by manufacturing plants in nine developing countries. Journal of Cleaner Production, 16(1): 67-77.

Madsen A N, Andersen P D (2010) Innovative regions and industrial clusters in hydrogen and fuel cell technology. Energy Policy, 38(10): 5372-5381.

Mans P, Alkemade F, van der Valk T, Hekkert M P (2008) Is cluster policy useful for the energy sector? Assessing self-declared hydrogen clusters in the Netherlands. Energy Policy, 36(4): 1375-1385.

METI (2010) On the new growth strategy. Ministry of Economy, Trade and Industry, Tokyo.

METI (2008) Cool earth-innovative energy technology program. Ministry of Economy, Trade and Industry, Tokyo.

METI (2006a) New national energy strategy (digest). Ministry of Economy, Trade and Industry, Tokyo.

METI (2006b) The industrial cluster policy of japan - co-operation among industry, government and academia. Shinya Okuda, Regional Economic and Industrial Policy Group, Tokyo, METI.

MEXT (2006) Cluster - knowledge cluster initiative 2006. Office for the Promotion of Regional $R \& D$ Activities. Ministry of Education, Culture, Sports, Science and Technology, Tokyo.

Mowery D C, Nelson R R, Martin B R (2010) Technology policy and global warming: why new policy models are needed (or why putting new wine in old bottles won't work). Research Policy, 39(8): 1011-1023.

Nakicenovic N (1996) Freeing energy from carbon. Daedalus, 125(3): 95-112.

NEDO (2007) Outline of NEDO: New Energy and industrial technology Development Organization 2007-2008. Tokyo: NEDO.

NEDO (2010) NEDO saiseikano enerugi gijutsu hakusho, Tokyo: NEDO.

NEF (2009) New Energy Finance Global Futures 2009, New Energy Finance, London.

Nikvist B, Whitmarsch L (2008) A multi-level analysis of sustainable mobility transitions: niche development in the UK and Sweden. Technological Forecasting and Social Change, 75(9): 1373-1387.

Nill J, Kemp R (2009) Evolutionary approaches for sustainable innovation policies: from niche to paradigm? Research Policy, 38 (4): 668-680.

NRC (2010) S\&T Strategies of six countries: implications for the United States. Committee on Global Science and Technology Strategies and Their Effect on U.S. National Security; National Research Council, Washington D.C.

NVCA (2010) 2010 National venture capital association yearbook. National Venture Capital Association, Arlington.

OECD (2010) OECD Economic Surveys: Korea. OECD Publications, Paris, vol.: 12.

OECD (2009) Sustainable manufacturing and ecoinnovation: towards a green economy. OECD Policy Brief, OECD Observer, June, OECD Publishing, Paris.

OECD (2008) Environmental innovation and global markets. Working Party on Global and Structural Policies, Document No. ENV/EPOC/ GSP(2007)2/Final, Paris: OECD Publishing.

Ojardias F (2010) La Corée du Sud investit massivement dans la croissance verte. La Tribune (http://ged.latribune.fr/zetasearch/hweb/index.html?DN_ART=483528). 
Ömer-Rieder B, Whitelegg K (2005) Moving out of the niche: integrating sustainable development and innovation policy in Austria. In OECD (ed.), Governance of Innovation System - Volume 3: Case Studies in Cross-Sectoral Policy, OECD Publishing, Paris: 271-296.

Payton S, Kneller P (2009) The future of cleantech in Europe. Caspian Publishing, London.

Pernick R, Wilder C, Gauntlett D, Winnie T (2010) Clean energy trends 2010. Clean Edge, Oakland.

Pessoa A, Rui Silva M (2009) Environment based innovation. policy questions. Finisterra - Revista Portuguesa de Geografia, XLIV(88): 53-78.

Porter M E (1991) America's green strategy. Scientific American, 264(4): 168.

REN21 (2010) Renewables 2010 global status report. REN21, Paris.

Robins N, Clover R, Singh C (2009) A climate for recovery: the colour of stimulus goes green. HSBC Global Research, Climate Change Global, London.

Smit T, Junginger M, Smits R (2007) Technological learning in offshore wind energy: different roles of the government. Energy Policy, 35(12): 6431-6444.

Smith A, Stirling A, Berkhout F (2005) The governance of sustainable socio-technical transitions. Research Policy, 34(10): 1491-1510.

Sojung Y (2010) Seoul to invest 40 trillion won in renewable energy sector. Korea.net (22/10/2010) (http://www.korea.net/news.do $?$ mode $=$ detail $\&$ thiscode $=$ eng $030008 \&$ gu $\mathrm{id}=50791$ ).

Steurer R (2007) From government strategies to strategic public management: an exploratory outlook on the pursuit of cross-sectoral policy integration. European Environment, 17(3): 201-214.
Suurs R A A, Hekkert M P (2009) Competition between first and second generation technologies: lessons from the formation of a biofuels innovation system in the Netherlands. Energy, 34(5): 669-679.

Torgemen E (2010) Chine: un pollueur decide a etre le leader des technos vertes. La Tribune, 17 août.

U.S. Department of Commerce (2010) Environmental technologies industries: FY2010 Industry Assessment. Office of Energy and Environmental Industries, Washington D.C.

UNEP (2010) Global trends in sustainable energy investment 2010: analysis of trends and issues in the financing of renewable energy and energy efficiency. Paris \& London, United Nations Environment Programme \& New Energy Finance.

UNEP/ILO (2008) Green jobs: towards decent work in a sustainable, low-carbon world. Nairobi: United Nations Environment Programme and International Labor Organization.

van der Vleuten E, Raven R (2006) Lock-in and change: distributed generation in Denmark in a long-term perspective. Energy Policy, 34(18): 3739-3748.

Vilaihongs N (2009) La Corée profite de la crise pour investir dans la R\&D et la croissance verte. $B E$ Corée, $\mathrm{n}^{\circ} 47$ (06/07/2009), Ambassade de France en Corée (http://www.bulletins-electroniques.com/actualites/59824.htm).

Wang X (2010) La Green Economy et son financement en Chine. Master Dissertation, University Nancy 2.

Wietschel M, Seydel P (2007) Economic impacts of hydrogen as an energy carrier in european countries. International Journal of Hydrogen Energy, 32(15): 3201-3211.

i Broadly speaking, an environmental innovation can be defined as a "new or modified processes, techniques, practices, systems and products to avoid or reduce environmental harms" (Beise and Rennings, 2005: 6).

ii UNEP (2010) gives a quite different amount ( $\$ 46.7$ billion) for the Chinese green economy stimulus plan. Indeed, within China as well, there seems to be a large gap between what is officially announced and what is really implemented. 